\title{
Contributions of the direct supply of belowground seagrass detritus and trapping of suspended organic matter to the sedimentary organic carbon stock in seagrass meadows
}

\author{
Toko Tanaya ${ }^{1}$, Kenta Watanabe ${ }^{1}$, Shoji Yamamoto ${ }^{2}$, Chuki Hongo ${ }^{3}$, Hajime Kayanne ${ }^{2}$, and Tomohiro Kuwae ${ }^{1}$ \\ ${ }^{1}$ Coastal and Estuarine Environment Research Group, Port and Airport Research Institute, 3-1-1 Nagase, \\ Yokosuka 239-0826, Japan \\ ${ }^{2}$ Department of Earth and Planetary Science, the University of Tokyo, Hongo 7-3-1, Bunkyo-ku, Tokyo 113-0033, Japan \\ ${ }^{3}$ Department of Chemistry, Biology, and Marine Science, University of the Ryukyus, Senbaru 1, Nishihara, \\ Okinawa 903-0213, Japan
}

Correspondence: Toko Tanaya (tanaya-t@p.mpat.go.jp)

Received: 5 December 2017 - Discussion started: 11 December 2017

Revised: 19 May 2018 - Accepted: 11 June 2018 - Published: 3 July 2018

\begin{abstract}
Carbon captured by marine living organisms is called "blue carbon", and seagrass meadows are a dominant blue carbon sink. However, our knowledge of how seagrass increases sedimentary organic carbon (OC) stocks is limited. We investigated two pathways of $\mathrm{OC}$ accumulation: trapping of organic matter in the water column and the direct supply of belowground seagrass detritus. We developed a new type of box corer to facilitate the retrieval of intact cores that preserve the structures of both sediments (including coarse sediments and dead plant structures) and live seagrasses. We measured seagrass density, total $\mathrm{OC}$ mass $\left(\mathrm{OC}_{\text {total }}\right)$ (live seagrass $\mathrm{OC}$ biomass $\left(\mathrm{OC}_{\mathrm{bio}}\right)+$ sedimentary $\mathrm{OC}$ mass $\left.\left(\mathrm{OC}_{\mathrm{sed}}\right)\right)$, and the stable carbon isotope ratio $\left(\delta^{13} \mathrm{C}\right)$ of $\mathrm{OC}_{\text {sed }}$ and its potential OC sources at Thalassia hemprichii dominated back-reef and Enhalus acoroides dominated estuarine sites in the tropical Indo-Pacific region. At points with vegetation, $\mathrm{OC}_{\text {bio }}$ accounted for $25 \%$ and $\mathrm{OC}_{\text {sed }}$ for $75 \%$ of $\mathrm{OC}_{\text {total }}$; this contribution of $\mathrm{OC}_{\mathrm{bio}}$ to $\mathrm{OC}_{\text {total }}$ is higher than in globally compiled data. Belowground detritus accounted for $\sim 90 \%$ of the OC mass of dead plant structures ( $>2 \mathrm{~mm}$ in size) $\left(\mathrm{OC}_{\text {dead }}\right)$. At the back-reef site, belowground seagrass biomass, $\mathrm{OC}_{\text {dead }}$, and $\delta^{13} \mathrm{C}$ of $\mathrm{OC}_{\text {sed }}\left(\delta^{13} \mathrm{C}_{\mathrm{sed}}\right)$ were positively correlated with $\mathrm{OC}_{\text {sed }}$, indicating that the direct supply of belowground seagrass detritus is a major mechanism of $\mathrm{OC}_{\text {sed }}$ accumulation. At the estuarine site, aboveground seagrass biomass was positively correlated with $\mathrm{OC}_{\text {sed }}$ but $\delta^{13} \mathrm{C}_{\text {sed }}$ did not correlate with $\mathrm{OC}_{\text {sed }}$, indicating that trapping of suspended OC by seagrass leaves is a major mech-
\end{abstract}

anism of $\mathrm{OC}_{\text {sed }}$ accumulation there. We inferred that the relative importance of these two pathways may depend on the supply (productivity) of belowground biomass. Our results indicate that belowground biomass productivity of seagrass meadows, in addition to their aboveground morphological complexity, is an important factor controlling their OC stock. Consideration of this factor will improve global blue carbon estimates.

\section{Introduction}

The carbon captured by marine living organisms has been termed "blue carbon" (Nelleman et al., 2009). Among marine ecosystems, the organic carbon (OC) accumulation rate of vegetated coastal systems such as seagrass meadows, mangrove forests, and salt marshes is estimated to be higher than that of terrestrial forests (Mcleod et al., 2011). The global total OC stock contained in the top $1 \mathrm{~m}$ of sediment and in the plant biomass in these vegetated ecosystems is estimated to be $0.63-8.54 \mathrm{Pg} \mathrm{C}$ (Pendleton et al., 2012). Thus, vegetated ecosystems are expected to contribute greatly to the mitigation of global warming. In this regard, seagrass meadows have attracted particular attention because they are one of the most dominant blue carbon sinks (Kennedy et al., 2010; Fourqurean et al., 2012). However, the OC stock of a seagrass meadow is highly variable, depending on geographical region (Miyajima et al., 2015), seagrass species (Lavery et 
al., 2013), microlocation within a seagrass patch (Ricart et al., 2015), and the patch scale (Miyajima et al., 2017). Hence, to develop a precise methodology of OC estimation and reduce the uncertainty of the global estimate, it is necessary to understand the factors controlling OC stocks in seagrass meadows (Duarte et al., 2013).

Seagrass meadows enhance the accumulation of sedimentary OC by directly supplying abundant $\mathrm{OC}$ from their high production (Duarte et al., 2010), by reducing sediment resuspension, and by promoting sedimentation of autochthonous and allochthonous $\mathrm{OC}$ in the water column (Agawin and Duarte, 2002; Gacia and Duarte, 2001; Gacia et al., 2003; Hendriks et al., 2008). However, our knowledge of the factors that mediate the sequestration of sedimentary OC by seagrass meadows is limited. For example, the chemical recalcitrance of the supplied organic matter (Trevathan-Tackett et al., 2017; Watanabe and Kuwae, 2015) and the specific surface area of the sediment (Miyajima et al., 2017) are factors that control the sedimentary OC stock in seagrass meadows. Recent studies have also shown that, in addition to chemical and physical factors, biological factors such as primary productivity, seagrass shoot density, and the amount of leaf material (as indicated by the leaf area index) also affect the sedimentary OC stock (Samper-Villarreal et al., 2016; Serrano et al., 2014, 2016b). In addition, an increase in the amount of leaf material may enhance the trapping of suspended OC and, thus, the accumulation of sedimentary OC (Dahl et al., 2016; Gacia et al., 1999). An increase in seagrass density may also cause an increase in seagrass production per unit area and thus enhance the direct supply of seagrass-derived OC. However, few previous studies have analyzed the controlling factors and provenance of sedimentary OC along a seagrass biomass gradient (Kennedy et al., 2004, 2010; Samper-Villarreal et al., 2016; Howard et al., 2018). Kennedy et al. (2004, 2010) and Howard et al. (2018) found no significant relationship between seagrass biomass and sedimentary OC, whereas Samper-Villarreal et al. (2016) concluded that autochthonous sedimentary OC increased as the leaf area index increased. However, they did not show the mechanism (pathway) by which seagrass-derived OC became sedimentary OC; that is, they did not show whether the seagrass trapped seagrass-derived OC suspended in the water column or directly supplied seagrass-derived carbon to the sediments.

To assess the effect of seagrass on the sedimentary OC stock, it is important to examine all stock components, including live and dead aboveground and belowground biomass in the sediment column, and their origins. For this reason, it is necessary to retrieve intact cores, because both macroscopic plant materials (Miyajima et al., 1998) and OC derived from calcareous organisms such as corals, foraminifera, molluscs, and coralline algae (Ingalls et al., 2003; Versteegh et al., 2011) occur in the coarse sediment fraction (sand and gravels), especially in tropical seagrass meadows around coral reefs (Suzuki, 2005). However, to our knowledge, all previous studies have only examined some of the stock components, for example, the fine sediment fraction (<1-2 mm diameter) (Hemminga et al., 1994; Miyajima et al., 2015; Kennedy et al., 2004; Ricart et al., 2015), dead plant structures (Cebrian et al., 2000), surface sediment (Barron et al., 2004), and small subsamples from a core (Dahl et al., 2016).

In this study, to investigate the pathways of sedimentary OC accumulation in seagrass meadows, especially the direct supply of belowground seagrass detritus, we used intact cores that included all live and dead seagrasses and sediments and then performed the OC mass and stable carbon isotope analyses of all components of the cores to examine the origin of the $\mathrm{OC}$ along a seagrass biomass gradient.

\section{Materials and methods}

\subsection{Study sites}

To assess the relationship between seagrass and the sedimentary OC stock, we chose tropical Indo-Pacific seagrass meadow sites. Globally, the tropical Indo-Pacific region is the world's largest bioregion and contains the highest diversity of seagrasses, which are distributed predominantly on coral reef flats (Short et al., 2007). Globally, the total documented seagrass area is $164000 \mathrm{~km}^{2}$ (Green and Short, 2003), and the total seagrass area in the Indo-Pacific region, excluding Australia, where both tropical and temperate seagrasses are distributed, is around $32400 \mathrm{~km}^{2}$, or about $20 \%$ of the total area. Furthermore, given that about half of the documented seagrass habitat in Australia is composed of tropical seagrasses (Kirkman, 1997), the total area of tropical IndoPacific seagrass habitat reaches approximately $116000 \mathrm{~km}^{2}$, accounting for $70 \%$ of the global seagrass area. Thus, accurate estimation of the blue carbon stock of seagrasses in the tropical Indo-Pacific region is important for the estimation of the global seagrass carbon stock. However, in spite of the geographical importance of this region, reports on seagrass OC stocks there are limited (Lavery et al., 2013; Miyajima et al., 2015).

We obtained cores from two Indo-Pacific tropical seagrass meadow sites from 13 to 23 August 2014. The two sites, a back-reef site (Shiraho reef) and an estuarine site (Fukido estuary), both located around Ishigaki, Okinawa, southwestern Japan (Fig. 1), have different allochthonous carbon input amounts. The back-reef site is situated on a well-developed reef flat about $1 \mathrm{~km}$ wide, where seagrass meadows, dominated by Thalassia hemprichii, are distributed between 100 and $300 \mathrm{~m}$ from the shoreline. The site is about $2 \mathrm{~km}$ south of the mouth of the Todoroki River, and most sediments transported by the river accumulate on its northern side (Mitsumoto et al., 2000) because the prevailing current, which is controlled by large channels in the reef, is northward (Tamura et al., 2007). Therefore, terrestrial sediment input to the back- 
reef site is low. The mud (silt + clay) content of the surface sediment of the seagrass meadows at the site ranges from 1.2 to $3.9 \%$ (mean $2.3 \%$ ) (Tanaka and Kayanne, 2007). The estuarine site is located near the mouth of a small river, which is bordered by small mangrove forests. The freshwater inflow is low, so water exchange between the river and estuary is controlled mainly by tidal motion (Terada et al., 2007). The dominant seagrass species at the site is Enhalus acoroides. The mud content of the surface sediment in the seagrass meadows at the estuarine site ranges from 0.9 to $6.4 \%$ (mean $3.6 \%$ ) (Tanaka and Kayanne, 2007).

\subsection{Core sampling}

We developed a new box corer to facilitate the retrieval of intact cores that preserve sedimentary structures as well as aboveground and belowground live and dead seagrasses (Fig. 2). The box corer is $15 \mathrm{~cm}$ wide, $15 \mathrm{~cm}$ deep, and $17 \mathrm{~cm}$ high and is made of stainless steel so that it can cut through roots and rhizomes. A shutter $1 \mathrm{~cm}$ above the bottom of the corer is designed to cut through the relatively hard belowground seagrasses, making it possible to obtain intact cores. The corer also has a lid to prevent the loss of surficial sediments from the core during underwater sampling. The corer is large enough to retrieve all components of the OC stock whole: shoots, live and dead aboveground and belowground seagrasses, and old skeletal OC in sand and gravel derived from calcareous organisms such as corals, foraminifera, molluscs, and coralline algae. Most cores obtained with the corer were about $15 \mathrm{~cm}$ long, but we were not able to insert the core to its full length at three sampling points because of the presence of large gravels in the sediment. We were able to collect all of the seagrass biomass at these points, however.

To measure the total $\mathrm{OC}$ mass $\left(\mathrm{OC}_{\text {total }}\right)$, we quantified three components of the box corer samples (Fig. 3): (1) live seagrasses $\left(\mathrm{OC}_{\mathrm{bio}}\right)$; (2) dead plant structures $(>2 \mathrm{~mm}$ in size: dead seagrass leaves, sheaths, rhizomes, and roots detached from live structures) $\left(\mathrm{OC}_{\text {dead }}\right)$; and (3) $\mathrm{OC}$ in the coarse (>1 mm diameter) sediments (excluding dead plant structures $>2 \mathrm{~mm}$ in size) $\left(\mathrm{OC}_{\mathrm{csed}}\right)$. We also collected samples with cylinder cores so that we could obtain depth profiles of OC in the fine $(<1 \mathrm{~mm}$ diameter) sediments (including dead plant structures $<1 \mathrm{~mm}$ in size) $\left(\mathrm{OC}_{\mathrm{fsed}}\right)$. It was technically impossible to obtain these profiles with the box corer because of its large surface sampling area and the high density of the belowground structures (Fig. 2c). The samples retrieved by the box corer were immediately sieved through a $1 \mathrm{~mm}$ mesh sieve in situ to obtain the $>1 \mathrm{~mm}$ fractions of the $\mathrm{OC}_{\mathrm{bio}}$, $\mathrm{OC}_{\text {dead }}$, and $\mathrm{OC}_{\mathrm{csed}}$. Live seagrasses have air-filled lacunae so that they float; thus, we considered buoyant seagrasses captured by the sieve to be $\mathrm{OC}_{\text {bio }}$ (Borum et al., 2006). We merged any dead plant structures attached to live seagrasses into $\mathrm{OC}_{\text {bio }}$ because their mass was usually very small. We collected a cylinder core $10-16 \mathrm{~cm}$ long with an acrylic pipe (internal diameter $6.6 \mathrm{~cm}$ ) from a point immediately adjacent
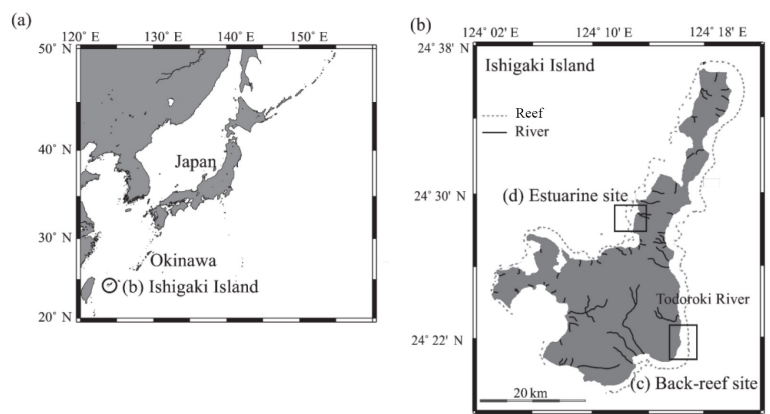

(c)

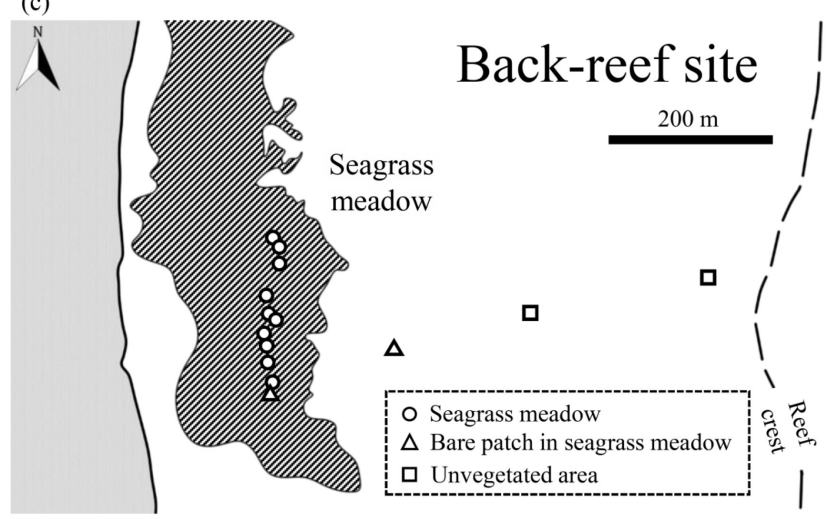

(d)

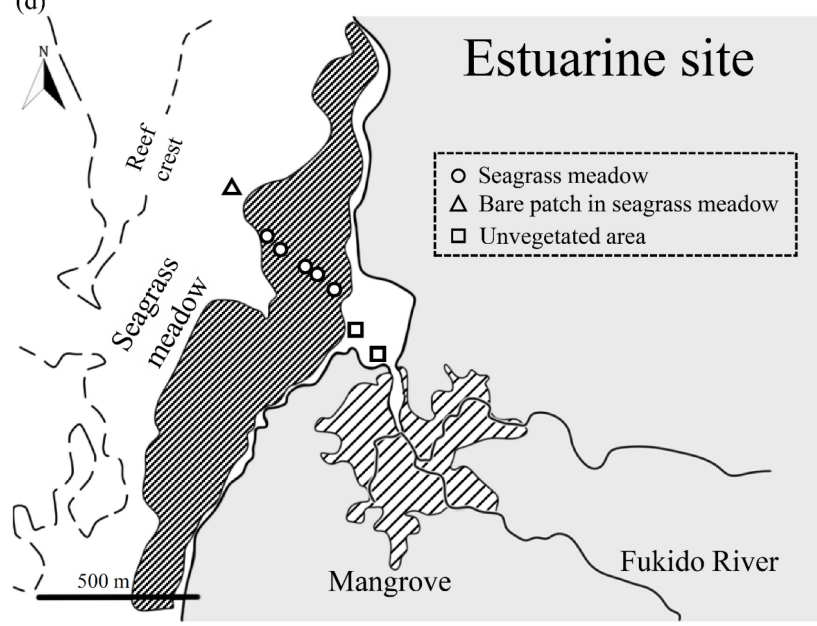

Figure 1. Study sites. (a, b) Study site location on Ishigaki, Japan. Sampling points at (c) the back-reef site and (d) the estuarine site. At the back-reef site, the circle indicating the southernmost vegetated sampling point actually represents a cluster of six sampling points.

to each box core. We subdivided each cylinder core into $1 \mathrm{~cm}$ long subsamples from the surface to the bottom of the core.

We obtained 20 paired samples (one box and one cylinder core) from the back-reef site and eight paired samples from the estuarine site. At the back-reef site, we collected 16 paired samples from vegetated points in the seagrass meadows, two from bare patches in the seagrass meadows, and two from unvegetated areas (Fig. 1c). Similarly, at the estuarine site, we collected five paired samples from vegetated 


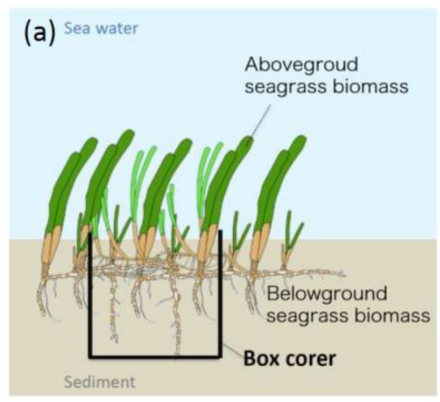

(b)

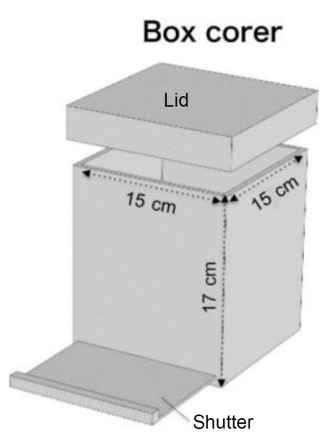

(c)

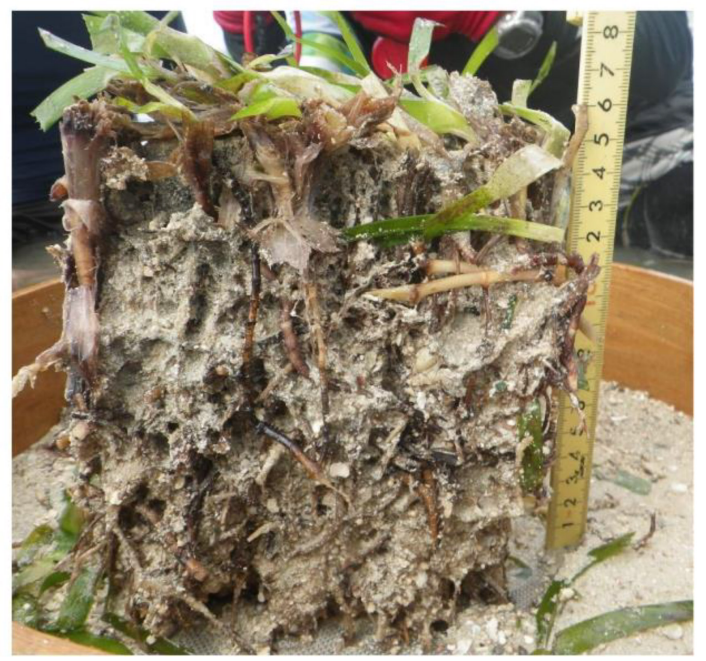

Figure 2. The newly developed box corer and a sampled core. Schematic diagrams of (a) a cross section of a core and (b) the design of the corer. (c) Photograph of a core from the back-reef site. The dominant seagrass species is Thalassia hemprichii.

points, one pair from a bare point, and two paired samples from unvegetated areas near the river mouth (Fig. 1d).

Potential sources of sedimentary $\mathrm{OC}\left(\mathrm{OC}_{\mathrm{sed}}\right)$ were also collected at both sites and analyzed for $\delta^{13} \mathrm{C}$. Samples of seagrass leaves were collected from all dominant seagrass species at each site: T. hemprichii, Cymodocea rotundata, $C$. serrulata, and Halodule uninervis at the back-reef site, and E. acoroides, T. hemprichii, and C. serrulata at the estuarine site. Samples for determining the $\delta^{13} \mathrm{C}$ of algae and corals were taken from epiphytes, benthic microalgae, and the dominant coral species (mainly Acropora spp. and Porites spp.) at the sites. Epiphytes were collected from the seagrass leaves by using a stainless steel scraper, and benthic microalgae were extracted from the surface sediment (up to approximately $1 \mathrm{~mm}$ depth) by the method of Kuwae et al. (2008). All obtained samples were stored in polyethylene bags at $-20^{\circ} \mathrm{C}$ until analysis.

We used the published $\delta^{13} \mathrm{C}$ data of suspended OC (collected about $1 \mathrm{~km}$ off the outer reef edge of Ishigaki) and of terrestrial particulate organic matter (POM; collected from the Fukido River, Ishigaki) from Miyajima et al. (2015). We

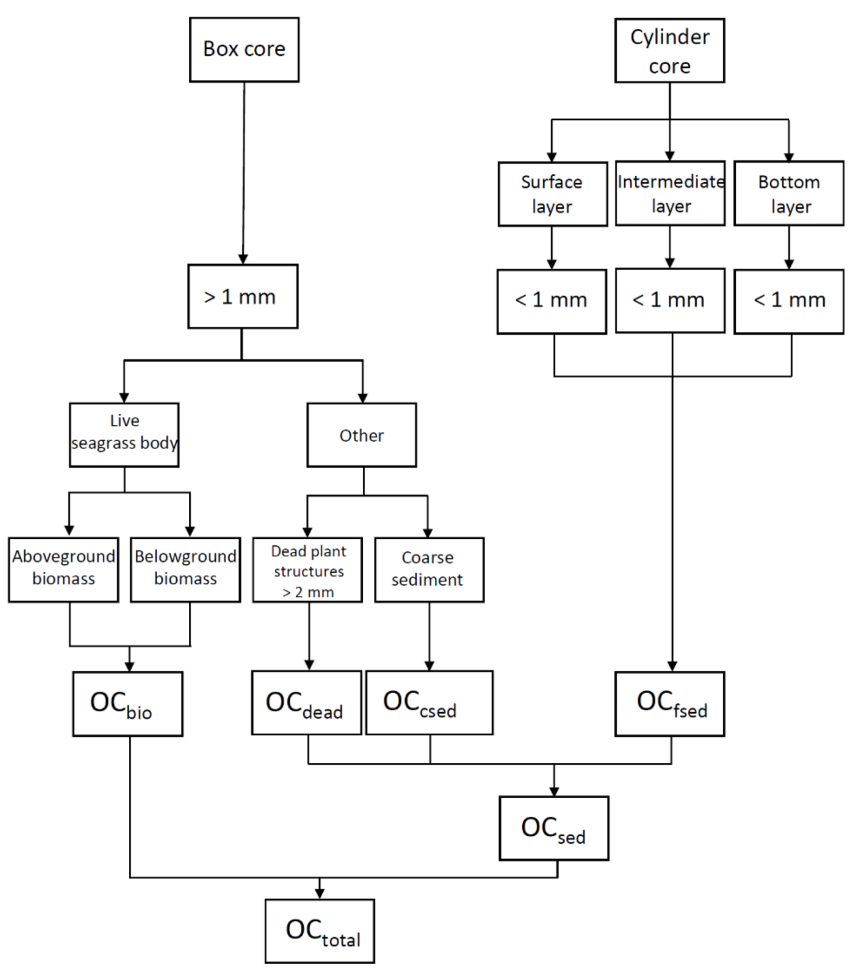

Figure 3. Calculation of total $\mathrm{OC}$ mass $\left(\mathrm{OC}_{\text {total }} ; \mathrm{g} \mathrm{C} \mathrm{m}^{-2}\right)$ in the top $0.15 \mathrm{~m}$ layer. $\mathrm{OC}_{\mathrm{sed}}$ is sedimentary $\mathrm{OC}, \mathrm{OC}_{\mathrm{bio}}$ is $\mathrm{OC}$ in live seagrasses, $\mathrm{OC}_{\text {dead }}$ is $\mathrm{OC}$ in dead plant structures $(>2 \mathrm{~mm}$ in size: dead seagrass leaves, sheaths, rhizomes, and roots detached from live structures), $\mathrm{OC}_{\mathrm{csed}}$ is $\mathrm{OC}$ in the coarse ( $>1 \mathrm{~mm}$ diameter) sediments (excluding dead plant structures $>2 \mathrm{~mm}$ in size), and $\mathrm{OC}_{\mathrm{fsed}}$ is OC in the fine ( $<1 \mathrm{~mm}$ diameter) sediments (including dead plant structures $<1 \mathrm{~mm}$ in size).

assumed that the published $\delta^{13} \mathrm{C}$ data were normally distributed.

\subsection{OC and stable isotope analysis}

We identified live seagrasses to the species level and separated aboveground biomass (leaf blades) from belowground biomass (leaf sheathes, rhizomes, and roots). Then we dried all parts at $60^{\circ} \mathrm{C}$ and weighed them. Box corer sediments were dried at $60^{\circ} \mathrm{C}$ and sieved through a $2 \mathrm{~mm}$ mesh sieve, and the included dead plant structures ( $>2 \mathrm{~mm}$ in size) were picked out and weighed. To ensure homogeneity of subsamples, the coarse sediments (excluding the dead plant structures) were first crushed to approximately $1 \mathrm{~mm}$ grains with a jaw crusher (Jaw Crusher PULVERISETTE 1 Model I classic line, FRITSCH, Ltd., Idar-Oberstein, Germany) and then divided into 16 or 64 subsamples with a splitter (Simple microsplitter, Iwamoto Mineral, Ltd., Tokyo, Japan). The cylinder core samples were subdivided into surface $(0-1 \mathrm{~cm}$ depth), intermediate (5-8 cm depth), and bottom (9-16 cm depth) layers and dried at $60^{\circ} \mathrm{C}$. For the $\mathrm{OC}_{\text {fsed }}$ analysis, each layer was sieved through a $1 \mathrm{~mm}$ mesh sieve and then subdi- 
vided into two or four subsamples with the splitter. All subsamples used for chemical analyses were weighed and then powdered and homogenized in an agate mill.

For OC analysis, the homogenized samples were placed in silver containers (to prevent the loss of acid-soluble OC in carbonate sediments) and pretreated with hydrochloric acid to remove carbonates (Yamamuro and Kayanne, 1995). First, each sample was weighed in a silver container and its weight was adjusted to about $20 \mathrm{mg}$. Then, $1 \mathrm{~N} \mathrm{HCl}$ was carefully and gradually added until bubbles were no longer seen, and the sample was dried at $60^{\circ} \mathrm{C}$ overnight and at $105^{\circ} \mathrm{C}$ for $1 \mathrm{~h}$. The dried sample was then wrapped in tin foil. We measured the total OC concentration and the stable carbon isotopic ratio of each sample with an elemental analyzer-connected isotope ratio mass spectrometer (FLASH EA 1112/DELTA ${ }^{\text {plus }}$ Advantage, Thermo Electron, Inc., Massachusetts, USA). The stable carbon isotope ratio $\left({ }^{13} \mathrm{C}\right)$ is reported as the relative per mil deviation from VPDB (Vienna Pee Dee Belemnite). The analytical precision of the isotope ratio mass spectrometer, based on the standard deviation of $\delta^{13} \mathrm{C}$ values of internal reference replicates, was $<0.2 \%$.

\subsection{Determination of the mass and $\delta^{13} \mathrm{C}$ of $\mathrm{OC}$}

We calculated $\mathrm{OC}_{\text {total }}$ per unit area $\left(\mathrm{g} \mathrm{C} \mathrm{m}^{-2}\right)$ at each sampling point by summing the $\mathrm{OC}_{\mathrm{bio}}$ and $\mathrm{OC}_{\mathrm{sed}}$ components in the top $0.15 \mathrm{~m}$ (Fig. 3) as follows:

$\mathrm{OC}_{\text {total }}=\mathrm{OC}_{\text {bio }}+\mathrm{OC}_{\text {sed }}$.

$\mathrm{OC}_{\text {bio }}$ was calculated as

$\mathrm{OC}_{\mathrm{bio}}=\sum_{i}\left(a_{i} x_{i}+b_{i} y_{i}\right)$,

where $a_{i}$ and $b_{i}$ are the averaged OC concentrations $\left(\mathrm{g} \mathrm{C} \mathrm{g}^{-1} \mathrm{DW}\right)$ of the aboveground and belowground biomasses, respectively, of the $i$ th seagrass species collected at three different sampling points (except $C$. serrulata, which was collected at only one sampling point at the estuarine site), and $x_{i}$ and $y_{i}$ are the aboveground and belowground biomasses $\left(\mathrm{g} \mathrm{m}^{-2}\right)$, respectively, of the $i$ th seagrass species. The biomasses of Syringodium isoetifolium, Halophila ovalis, and an unidentified species at the backreef site accounted for $<0.1 \%$ of the total biomass, so they were excluded from this calculation. The averaged OC concentrations and aboveground and belowground biomass dry weights are summarized in Table 1.

$\mathrm{OC}_{\text {sed }}$ was calculated as follows:

$\mathrm{OC}_{\text {sed }}=\mathrm{OC}_{\text {dead }}+\mathrm{OC}_{\mathrm{csed}}+\mathrm{OC}_{\text {fsed }}$.

The terms of Eq. (3) were calculated by the following equations:

$$
\begin{aligned}
\mathrm{OC}_{\text {dead }} & =\frac{1}{100}\left(\% \mathrm{OC}_{\text {leaf }} \times \rho_{\text {leaf }}+\% \mathrm{OC}_{\text {shrh }} \times \rho_{\text {shrh }}\right. \\
& \left.+\% \mathrm{OC}_{\text {root }} \times \rho_{\text {root }}\right) \times h, \\
\mathrm{OC}_{\text {csed }} & =\frac{1}{100}\left(\% \mathrm{OC}_{\text {csed }} \times \rho_{\text {csed }}\right) \times h,
\end{aligned}
$$

$$
\begin{aligned}
\mathrm{OC}_{\mathrm{fsed}} & =\frac{1}{3} \times \frac{1}{100}\left(\% \mathrm{OC}_{\mathrm{fseds}} \times \rho_{\mathrm{fseds}}\right. \\
& \left.+\% \mathrm{OC}_{\mathrm{fsedm}} \times \rho_{\mathrm{fsedm}}+\% \mathrm{OC}_{\mathrm{fsedb}} \times \rho_{\mathrm{fsedb}}\right) \times h,
\end{aligned}
$$

where \%OC is the concentration of OC (\% DW) $(n=3) ; \rho$ is the dry density $\left(\mathrm{g} \mathrm{DW} \mathrm{m}^{-3}\right)$ of each component (indicated by subscripts: leaf, dead leaf; shrh, dead sheath and rhizome; root, dead root; csed, coarse sediment; fseds, fine sediment of the surface layer; fsedm, fine sediment of the intermediate layer; fsedb, fine sediment of the bottom layer), and $h$ is the sample thickness $(0.15 \mathrm{~m}) . \mathrm{OC}_{\mathrm{fsed}}$ is the averaged $\mathrm{OC}$ mass of the three layers (surface, medium, and bottom) of fine sediment.

$\delta^{13} \mathrm{C}$ of $\mathrm{OC}_{\text {sed }}\left(\delta^{13} \mathrm{C}_{\mathrm{sed}}\right)$ at each sampling point was calculated as follows:

$$
\begin{aligned}
\delta^{13} \mathrm{C}_{\mathrm{sed}} & =\frac{1}{\mathrm{OC}_{\text {sed }}}\left(\mathrm{OC}_{\text {dead }} \times \delta^{13} \mathrm{C}_{\text {dead }}+\mathrm{OC}_{\mathrm{csed}}\right. \\
& \left.\times \delta^{13} \mathrm{C}_{\mathrm{csed}}+\delta^{13} \mathrm{C}_{\text {fsed }}\right),
\end{aligned}
$$

where $\delta^{13} \mathrm{C}_{\text {dead }}$ is the averaged $\delta^{13} \mathrm{C}$ value of dead plant structures (sheath and rhizomes, and roots) at the back-reef and estuarine sites. We did not include leaf detritus in the calculation of $\delta^{13} \mathrm{C}_{\text {sed }}$ because (1) the leaf fragments were so small that we could not remove epiphytes from them, and (2) their mass was much smaller than that of the sheath and rhizomes and roots, so we considered its contribution to $\delta^{13} \mathrm{C}_{\text {sed }}$ to be negligible. We used the $\delta^{13} \mathrm{C}_{\text {dead }}$ value at each site for the calculation of $\delta^{13} \mathrm{C}_{\text {sed. }}$. The standard deviation (SD) of $\delta^{13} \mathrm{C}_{\text {sed }}$ derived from the SD of $\delta^{13} \mathrm{C}_{\text {dead }}$ was smaller than $0.1 \%$ o. $\delta^{13} \mathrm{C}_{\text {csed }}$ is the $\delta^{13} \mathrm{C}$ value of $\mathrm{OC}_{\text {csed }} . \delta^{13} \mathrm{C}_{\text {fsed }}$ is the averaged $\delta^{13} \mathrm{C}$ value of $\mathrm{OC}_{\text {fsed }}$ multiplied by the $\mathrm{OC}$ mass of each layer and was calculated as follows:

$$
\begin{aligned}
\delta^{13} \mathrm{C}_{\mathrm{fsed}} & =\frac{1}{3} \times \frac{1}{100}\left(\% \mathrm{OC}_{\mathrm{fseds}} \times \rho_{\mathrm{fseds}}\right. \\
& \times \delta^{13} \mathrm{C}_{\mathrm{fseds}}+\% \mathrm{OC}_{\mathrm{fsedm}} \times \rho_{\mathrm{fsedm}} \times \delta^{13} \mathrm{C}_{\mathrm{fsedm}} \\
& \left.+\% \mathrm{OC}_{\mathrm{fsedb}} \times \rho_{\mathrm{fsedb}} \times \delta^{13} \mathrm{C}_{\mathrm{fsedb}}\right) \times h .
\end{aligned}
$$

The averaged values of the organic carbon concentration, $\delta^{13} \mathrm{C}$, and dry density of sediment and dead plant structures are summarized in Table 2.

\section{Results}

\subsection{Seagrass biomass and species composition at each site}

At the back-reef site, the average $( \pm \mathrm{SD})$ aboveground and belowground biomass values were $74 \pm 45 \mathrm{~g} \mathrm{DW} \mathrm{m}^{-2}$ $(n=16)$ and $675 \pm 450 \mathrm{~g} \mathrm{DW} \mathrm{m}^{-2}(n=16)$, respectively (Table 1). The dominant species was $T$. hemprichii, accounting for $76.7 \%$ of the total biomass; C. rotundata $(18.0 \%)$, C. serrulata (3.3\%), H. uninervis $(1.7 \%), H$. 
Table 1. Organic carbon contents and dry weights of each component of living biomass at the back-reef and estuarine sites.

\begin{tabular}{lrr|rr}
\hline & \multicolumn{2}{c|}{ Back-reef } & \multicolumn{2}{c}{ Estuary } \\
\cline { 2 - 5 } & $\begin{array}{r}\% \mathrm{OC}(\% \mathrm{DW}) \\
\text { mean } \pm \mathrm{SD}(n)\end{array}$ & $\begin{array}{r}\text { Dry weight }\left(\mathrm{g} \mathrm{m}^{-2}\right) \\
\text { mean } \pm \mathrm{SD}(n)\end{array}$ & $\begin{array}{r}\% \text { OC }(\% \mathrm{DW}) \\
\text { mean } \pm \mathrm{SD}(n)\end{array}$ & $\begin{array}{r}\text { Dry weight }\left(\mathrm{g} \mathrm{m}^{-2}\right) \\
\text { mean } \pm \mathrm{SD}_{(n)}\end{array}$ \\
\hline Aboveground biomass & $38.47 \pm 3.06(39)$ & $74 \pm 45(16)$ & $35.95 \pm 2.28(20)$ & $70 \pm 34(5)$ \\
Belowground biomass & $31.35 \pm 2.93(20)$ & $675 \pm 450(16)$ & $30.38 \pm 2.55(13)$ & $1354 \pm 847(5)$ \\
\hline
\end{tabular}

Table 2. Organic carbon content, $\delta^{13} \mathrm{C}$, and dry density of each of sediment and dead plant component at the back-reef and estuarine sites.

\begin{tabular}{|c|c|c|c|c|c|c|}
\hline & \multicolumn{3}{|c|}{ Back-reef } & \multicolumn{3}{|c|}{ Estuary } \\
\hline & \multicolumn{2}{|c|}{ Organic carbon } & \multirow{2}{*}{ 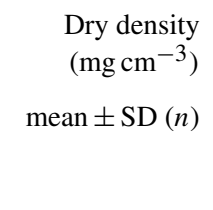 } & \multicolumn{2}{|c|}{ Organic carbon } & \multirow{2}{*}{ 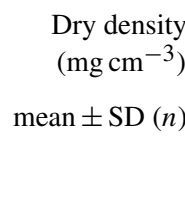 } \\
\hline & $\begin{array}{l}\% \mathrm{OC}(\% \mathrm{DW}) \\
\text { mean } \pm \mathrm{SD}(n)\end{array}$ & $\begin{array}{r}\delta^{13} \mathrm{C} \\
(\% \circ \text { vs. VPDB) } \\
\text { mean } \pm \mathrm{SD}(n)\end{array}$ & & $\begin{array}{l}\% \mathrm{OC}(\% \mathrm{DW}) \\
\text { mean } \pm \mathrm{SD}(n)\end{array}$ & $\begin{array}{r}\delta^{13} \mathrm{C} \\
(\% \circ \text { vs. VPDB }) \\
\text { mean } \pm \mathrm{SD}(n)\end{array}$ & \\
\hline Fine sediment & $0.37 \pm 0.13(60)$ & $-12.8 \pm 0.8(60)$ & $893 \pm 303(60)$ & $0.42 \pm 0.20(24)$ & $-17.4 \pm 3.6(24)$ & $760 \pm 294(24)$ \\
\hline Coarse sediment & $0.32 \pm 0.13(20)$ & $-12.8 \pm 1.1(20)$ & $292 \pm 152(20)$ & $0.26 \pm 0.08$ & $-15.9 \pm 1.5(8)$ & $475 \pm 142(8)$ \\
\hline Dead leaf & $24.80 \pm 3.07(3)$ & $-8.9 \pm 0.6^{\mathrm{a}}(5)$ & $0.05 \pm 0.04(20)$ & $23.31 \pm 3.86^{\mathrm{b}}(3)$ & $-9.3 \pm 0.2^{\mathrm{a}}(5)$ & $0.03 \pm 0.04(8)$ \\
\hline Dead sheath and rhizome & $21.29 \pm 4.07(3)$ & $-8.9 \pm 0.6^{\mathrm{a}}(5)$ & $0.55 \pm 0.63(20)$ & $27.52 \pm 1.75^{\mathrm{b}}(3)$ & $-9.3 \pm 0.2^{\mathrm{a}}(5)$ & $1.44 \pm 1.86(8)$ \\
\hline Dead root & $19.25 \pm 1.67(3)$ & $-8.9 \pm 0.6^{\mathrm{a}}(5)$ & $0.26 \pm 0.25(20)$ & $19.94 \pm 5.89^{\mathrm{b}}(3)$ & $-9.3 \pm 0.2^{\mathrm{a}}(5)$ & $0.31 \pm 0.35$ \\
\hline
\end{tabular}

${ }^{\mathrm{a}}$ Total of sheath and rhizomes, and root. ${ }^{\mathrm{b}}$ At one sampling point (FS1) where the dominant species was different, the values were dead leaf, $25.77 \%$; dead sheath and rhizome, 19.05\%; and dead root, $19.21 \%$.

ovalis $(<0.1 \%)$, S. isoetifolium $(<0.1 \%)$, and an unidentified species $(<0.1 \%)$ were minor components at the backreef site. At the estuarine site, the average aboveground and belowground biomasses were $70 \pm 34 \mathrm{~g} \mathrm{DW} \mathrm{m}^{-2}(n=5)$ and $1354 \pm 847 \mathrm{~g} \mathrm{DW} \mathrm{m}^{-2}(n=5)$, respectively (Table 1$)$. The dominant species was $E$. acoroides, accounting for $92.3 \%$ of the total biomass; T. hemprichii $(7.0 \%)$, C. serrulata $(0.6 \%)$, and $H$. uninervis $(<0.1 \%)$ were minor components.

\subsection{OC mass}

The average OC density $\left(\mathrm{g} \mathrm{C} \mathrm{cm}^{-3}\right)$ did not differ significantly among the fine sediment layers at either the back-reef site (paired $t$-test, Bonferroni adjusted $P>0.05$ ) or the estuarine site (Wilcoxon signed rank test, Bonferroni adjusted $P>0.05)$. The averaged $\mathrm{OC}_{\text {bio }}, \mathrm{OC}_{\text {dead }}, \mathrm{OC}_{\text {fsed }}, \mathrm{OC}_{\text {sed }}$, and $\mathrm{OC}_{\text {total }}$ values were significantly higher at points with vegetation than at points without vegetation at both the backreef site $\left(\mathrm{OC}_{\text {bio }}, t=-6.23\right.$, d.f. $=15, P<0.001 ; \mathrm{OC}_{\text {dead }}$, $W=0, P<0.001 ; \mathrm{OC}_{\mathrm{fsed}}, t=-2.61$, d.f. $=18, P=0.018$; $\mathrm{OC}_{\text {sed }}, t=-2.85$, d.f. $=18, P=0.011 ; \mathrm{OC}_{\text {total }}, t=-3.44$, d.f. $=18, P=0.003$ ) (Fig. $4 \mathrm{a}$ and $\mathrm{b}$ ) and the estuarine site $\left(\mathrm{OC}_{\text {bio }}, t=-3.61\right.$, d.f. $=4, P=0.022 ; \mathrm{OC}_{\text {dead }}, W=0$, $P=0.036 ; \mathrm{OC}_{\mathrm{fsed}}, t=-2.59$, d.f. $=6, P=0.041 ; \mathrm{OC}_{\mathrm{sed}}$, $t=-3.33$, d.f. $=6, P=0.016 ; \mathrm{OC}_{\mathrm{total}}, t=-4.24$, d.f. $=6$, $P=0.005$ ) (Fig. $4 \mathrm{c}$ and d). At points with vegetation, the averaged $\mathrm{OC}_{\mathrm{fsed}}$ and $\mathrm{OC}_{\text {sed }}$ values did not significantly differ between the sites $\left(\mathrm{OC}_{\mathrm{fsed}}, t=0.33\right.$, d.f. $=19, P>0.05$; $\mathrm{OC}_{\text {sed }}, t=-1.53$, d.f. $\left.=19, P>0.05\right)$, whereas the aver- aged $\mathrm{OC}_{\text {bio }}, \mathrm{OC}_{\text {dead }}, \mathrm{OC}_{\mathrm{csed}}$ and $\mathrm{OC}_{\text {total }}$ values were significantly higher at the estuarine site than at the backreef site $\left(\mathrm{OC}_{\text {bio }}, t=-2.25\right.$, d.f. $=19, P=0.036$; $\mathrm{OC}_{\text {dead }}$, $W=11, P=0.015 ; \mathrm{OC}_{\mathrm{csed}}, t=-4.86$, d.f. $=19, P<0.001$; $\mathrm{OC}_{\text {total }}, t=-2.34$, d.f. $=19, P=0.030$ ) (Fig. $4 \mathrm{~b}$ and d). At points with vegetation, $\mathrm{OC}_{\text {total }}$ ranged from 531 to $1785 \mathrm{~g} \mathrm{C} \mathrm{m}^{-2}$ across both sites. $\mathrm{OC}_{\mathrm{sed}}$, which ranged from 433 to $1147 \mathrm{~g} \mathrm{C} \mathrm{m}^{-2}$ and was the main component of $\mathrm{OC}_{\text {total }}$, accounted for $75.1 \pm 13.1 \% \mathrm{DW}$ of $\mathrm{OC}_{\text {total }}$. Hence, the contribution of the live seagrass itself $\left(\mathrm{OC}_{\mathrm{bio}}\right)$ was minor $(24.9 \pm 13.1 \% \mathrm{DW})$. $\mathrm{OC}_{\mathrm{fsed}}$ was the major component of $\mathrm{OC}_{\text {sed }}$, accounting for $55.6 \pm 12.5 \% \mathrm{DW}$ of $\mathrm{OC}_{\text {total }}$; $\mathrm{OC}_{\mathrm{csed}}$ and $\mathrm{OC}_{\text {dead }}$ were minor components, accounting for $15.0 \pm 7.2 \% \mathrm{DW}$ and $4.5 \pm 4.1 \% \mathrm{DW}$ of $\mathrm{OC}_{\text {total }}$, respectively.

The average aboveground and belowground biomasses in $\mathrm{OC}_{\mathrm{bio}}$ did not differ significantly between the sites (Fig. 5a) (aboveground biomass, $t=0.30$, d.f. $=19, P>0.05$; belowground biomass, $t=-1.75$, d.f. $=4.67, P>0.05$ ). Belowground biomass accounted for $89.1 \pm 4.4 \% \mathrm{DW}$ of $\mathrm{OC}_{\text {bio }}$ (Fig. 5b). The averaged biomasses of aboveground (i.e., leaf) and belowground (i.e., sheath and rhizome, and root) detritus in $\mathrm{OC}_{\text {dead }}$ did not differ significantly between the sites (aboveground detritus, $t=0.60$, d.f. $=7.82, P>0.05$; belowground detritus, $W=28, P>0.05$ ) (Fig. $5 \mathrm{c}$ ). The biomass of belowground detritus accounted for $90.8 \pm 12.0 \%$ DW of $\mathrm{OC}_{\text {dead }}$ (Fig. 5d). The biomasses of sheath and rhizome, and root, accounted for $65.5 \pm 19.2 \% \mathrm{DW}$ and $25.3 \pm 16.0 \%$ DW of $\mathrm{OC}_{\text {dead }}$, respectively. 

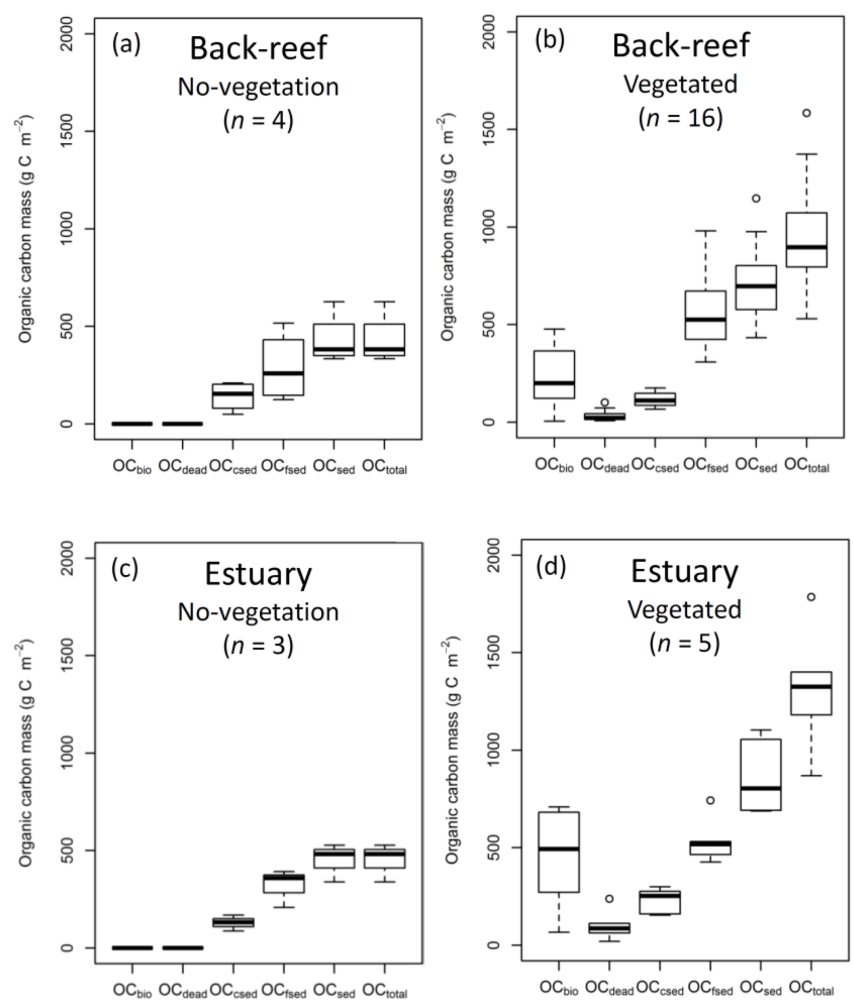

Figure 4. $\mathrm{OC}$ mass $\left(\mathrm{OC}_{\mathrm{bio}}, \mathrm{OC}_{\mathrm{dead}}, \mathrm{OC}_{\mathrm{csed}}, \mathrm{OC}_{\mathrm{fsed}}, \mathrm{OC}_{\mathrm{sed}}\right.$, and $\mathrm{OC}_{\text {total }}$ ) at (a) no-vegetation (bare and unvegetated) points at the back-reef site, (b) vegetated points at the back-reef site, (c) novegetation points at the estuarine site, and (d) vegetated points at the estuarine site. Boxes show the 25 and $75 \%$ quantiles; horizontal bands inside the boxes are median values; whiskers show maximum and minimum values; and the open circles are outliers.

\section{$3.3 \quad \delta^{13} \mathrm{C}$ of $\mathrm{OC}$}

The average $\delta^{13} \mathrm{C}_{\mathrm{sed}}$ at the back-reef site $(-12.6 \pm 0.7 \%$ o) was significantly higher than that of the estuarine site $(-16.6 \pm 3.1 \% o)(t=3.61$, d.f. $=7, P=0.008)$, and it was also significantly higher than the $\delta^{13} \mathrm{C}$ values of algae and corals $(-15.2 \pm 1.9 \%)(W=2753, P<0.001)$, suspended POM $(-21.9 \pm 1.6 \% o) \quad(t=15.45$, d.f. $=8, \quad P<0.001)$, and terrestrial POM $(-28.7 \pm 1.5 \%)(t=29.25$, d.f. $=8$, $P<0.001)$. However, average $\delta^{13} \mathrm{C}_{\text {sed }}$ at the back-reef site was significantly lower than $\delta^{13} \mathrm{C}$ of seagrass $(-9.2 \pm 1.3 \%$ ) $(t=-12.64$, d.f. $=57, P<0.001)$ (Fig. 6). Average $\delta^{13} \mathrm{C}_{\mathrm{sed}}$ at the estuarine site did not differ significantly from $\delta^{13} \mathrm{C}$ of algae and corals $(W=457, P>0.05)$, but it was significantly higher than $\delta^{13} \mathrm{C}$ of both suspended POM $(t=4.36$, d.f. $=14, P<0.001)$ and terrestrial POM $(t=10.05$, d.f. $=14, P<0.001)$, and significantly lower than $\delta^{13} \mathrm{C}$ of seagrass $(t=-6.66$, d.f. $=8, P<0.001)$. The average $\delta^{13} \mathrm{C}$ among fine sediment layers did not differ significantly at either the back-reef site (Wilcoxon signed rank test, Bonferroni adjusted $P>0.05$ ) or the estuarine site (paired $t$ test, Bonferroni adjusted $P>0.05$ ).

\subsection{Relationships among biomass, OC mass, and $\delta^{13} \mathrm{C}$}

At the back-reef site, we found significant correlations between $\mathrm{OC}_{\text {sed }}$ and DW-based (not carbon-based) biomass $\left(F_{1,18}=11.63, P=0.003, r^{2}=0.39\right)($ Fig. $7 \mathrm{a}), \mathrm{OC}_{\text {sed }}$ and aboveground biomass $\left(F_{1,18}=16.38, P<0.001, r^{2}=0.48\right)$ (Fig. 7b), $\mathrm{OC}_{\mathrm{sed}}$ and belowground biomass $\left(F_{1,18}=10.95\right.$, $\left.P=0.004, \quad r^{2}=0.38\right) \quad$ (Fig. $\quad 7 \mathrm{c}$ ), $\quad \mathrm{OC}_{\mathrm{sed}}$ and $\mathrm{OC}_{\text {dead }}$ $\left(F_{1,18}=4.55, P=0.047, r^{2}=0.20\right)($ Fig. $7 \mathrm{~d})$, and $\mathrm{OC}_{\text {sed }}$ and $\delta^{13} \mathrm{C}_{\text {sed }}\left(F_{1,18}=11.51, P=0.003, r^{2}=0.39\right)$ (Fig. 7e). We also found significant correlations between $\delta^{13} \mathrm{C}_{\text {sed }}$ and belowground biomass $\left(F_{1,18}=4.68, P=0.044, r^{2}=0.21\right)$ (Fig. 7f), and between $\delta^{13} \mathrm{C}_{\text {sed }}$ and $\mathrm{OC}_{\text {dead }}\left(F_{1,18}=13.18\right.$, $P=0.002, r^{2}=0.42$ ) (Fig. $7 \mathrm{~g}$ ). We also found significant positive correlations between aboveground and belowground biomass $\left(F_{1,18}=94.10, P<0.001, r^{2}=0.84\right)$. At the estuarine site, we found significant correlations between $\mathrm{OC}_{\text {sed }}$ and aboveground biomass $\left(F_{1,6}=8.18, P=0.029, r^{2}=0.58\right)$ (Fig. 7b) and between $\mathrm{OC}_{\text {sed }}$ and $\mathrm{OC}_{\text {dead }}\left(F_{1,6}=6.94\right.$, $P=0.039, r^{2}=0.54$ ) (Fig. 7d) but not between $\mathrm{OC}_{\text {sed }}$ and biomass $\left(F_{1,6}=3.08, P>0.05, r^{2}=0.34\right)($ Fig. $7 \mathrm{a}), \mathrm{OC}_{\mathrm{sed}}$ and belowground biomass (Fig. $7 \mathrm{c})\left(F_{1,6}=2.94, P>0.05\right.$, $\left.r^{2}=0.33\right)$, or $\mathrm{OC}_{\text {sed }}$ and $\delta^{13} \mathrm{C}_{\text {sed }}\left(F_{1,6}=0.040, P>0.05\right.$, $r^{2}<0.01$ ) (Fig. 7e). The slope of the regression line of $\mathrm{OC}_{\text {sed }}$ against aboveground biomass did not differ significantly between the sites (ANCOVA, $F=1.09$, d.f. $=1, P>0.05$ ) (Fig. 7b), and that of $\mathrm{OC}_{\text {sed }}$ against $\mathrm{OC}_{\text {dead }}$ also did not differ significantly between the sites $(F=0.36$, d.f. $=1, P>0.05)$ (Fig. 7d). We also found significant positive correlations between aboveground and belowground biomass $\left(F_{1,6}=78.40\right.$, $\left.P<0.001, r^{2}=0.93\right)$.

\section{Discussion}

\subsection{Components of OC stock in seagrass meadows}

Our results showed that the sedimentary $\mathrm{OC}$ mass $\left(\mathrm{OC}_{\mathrm{sed}}\right)$ was the main component of the total organic carbon mass $\left(\mathrm{OC}_{\text {total }}\right.$; i.e., all stock components: live and dead aboveground and belowground biomass and sediments) at our study sites. The averaged $\mathrm{OC}_{\text {bio }}$ was significantly higher in this study than that in the previous study by Fourqurean et al. (2012) ( $W=1691, P=0.006)$, whereas the averaged $\mathrm{OC}_{\text {sed }}$ was significantly lower in this study than in the previous study at both vegetated and no-vegetation points (vegetation, $W=6952, P<0.001$; no-vegetation, $W=225$, $P=0.036$ ) (Table 3). Hence, the contribution of $\mathrm{OC}_{\text {bio }}$ to $\mathrm{OC}_{\text {total }}$ at our sites was higher than the global average. The high $\mathrm{OC}_{\text {bio }}$ was due to the well-developed belowground biomass, which accounted for $90.8 \pm 3.9 \%$ of DW-based biomass at our sites. This value is also among the highest among globally compiled data (Duarte and Chiscano, 1999). Possible reasons for the exceptional development of belowground biomass include (1) morphological plasticity for re- 

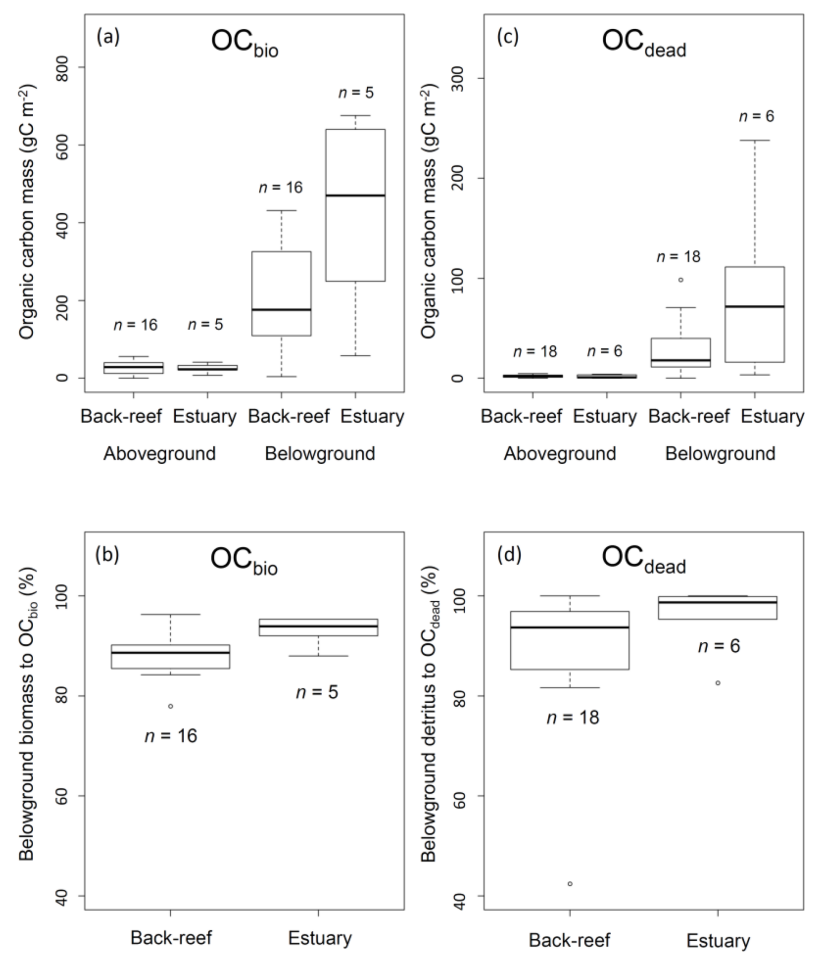

Figure 5. (a) $\mathrm{OC}_{\mathrm{bio}}$ (sum of aboveground and belowground biomass) $\left(\mathrm{g} \mathrm{C} \mathrm{m}^{-2}\right)$; (b) contribution of belowground biomass to $\mathrm{OC}_{\text {bio }}(\%)$; (c) $\mathrm{OC}_{\text {dead }}$ (sum of aboveground and belowground detritus $\left(\mathrm{g} \mathrm{C} \mathrm{m}^{-2}\right)$; and (d) contribution of belowground detritus to $\mathrm{OC}_{\mathrm{dead}}(\%)$. Boxes show the 25 and $75 \%$ quantiles; horizontal bands inside the box are median values; whiskers show maximum and minimum values; and open circles show outliers. (a) and (b) show the data of vegetated sampling points and (c) and (d) show the data of vegetated and bare sampling points.

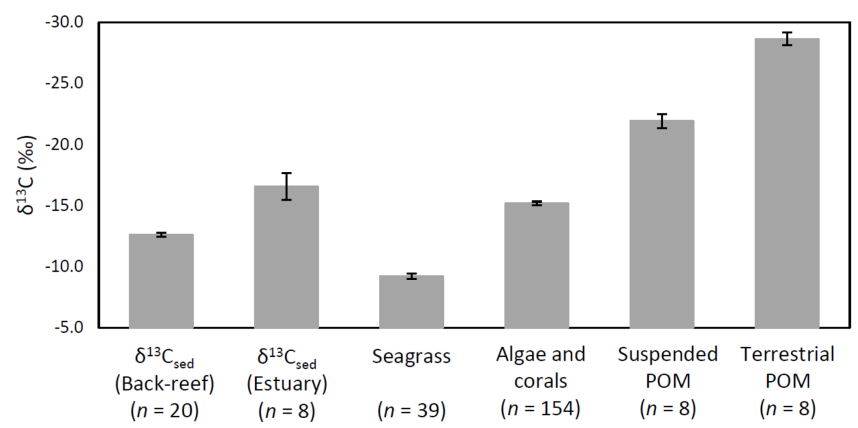

Figure 6. $\delta^{13} \mathrm{C}_{\mathrm{sed}}$ at each site and the $\delta^{13} \mathrm{C}$ values of potential sources of OC of $\delta^{13} \mathrm{C}_{\text {sed }}$ (means $\pm \mathrm{SE}$ ).

sistance to high wave energy (Fonseca and Bell, 1998), which is supported by the low mud content at our sites compared to that reported by previous studies (Koch, 2001; Serrano et al., 2016a), and (2) nutrient limitation, which can lead to more allocation of biomass to belowground parts to enable the plant to acquire nutrients in deeper sediment layers (Lee et al., 2007). The low $\mathrm{OC}_{\text {sed }}$ may be attributable to (1) high
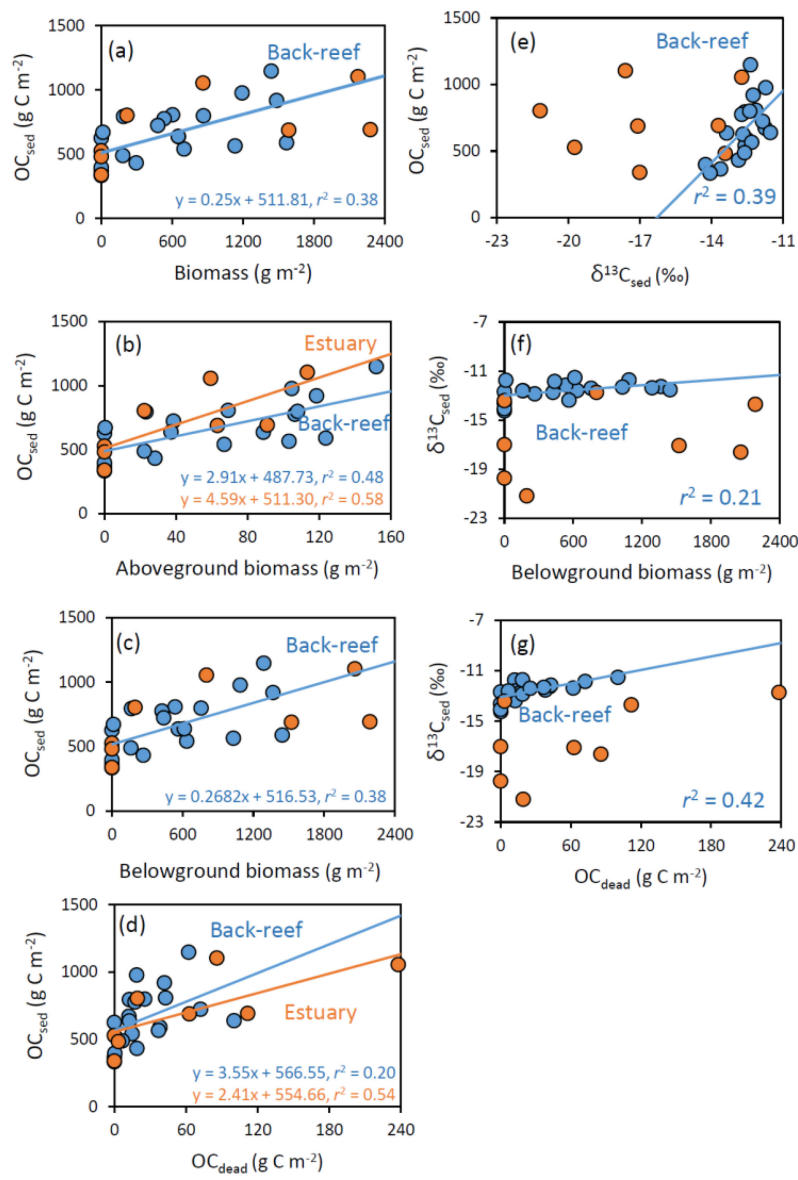

Figure 7. Relationships at the back-reef (blue) and estuarine (orange) sites between $\mathrm{OC}_{\text {sed }}$ and (a) biomass $\left(\mathrm{g} \mathrm{m}^{-2}\right)$, (b) aboveground biomass $\left(\mathrm{g} \mathrm{m}^{-2}\right)$, (c) belowground biomass $\left(\mathrm{g} \mathrm{m}^{-2}\right)$, and (d) $\mathrm{OC}_{\mathrm{dead}}\left(\mathrm{g} \mathrm{Cm}^{-2}\right)$, and between (e) $\mathrm{OC}_{\mathrm{sed}}$ and $\delta^{13} \mathrm{C}_{\mathrm{sed}}$, (f) $\delta^{13} \mathrm{C}_{\text {sed }}$ and belowground biomass, and (g) $\delta^{13} \mathrm{C}_{\text {sed }}$ and $\mathrm{OC}_{\mathrm{dead}}$.

wave energy in association with increased OC lability due to the low specific surface area of sediments (Miyajima et al., $2017)$ and (2) the low gross primary production/respiration $(P / R)$ ratio in this geographical region (Duarte et al., 2010).

Belowground detritus (i.e., sheath and rhizome, and root) was the major component of $\mathrm{OC}_{\text {dead }}$, accounting for $90.8 \pm 12.0 \%$ of $\mathrm{OC}_{\text {dead }}$ at our sites. This result is consistent with a previous report on Cymodocea nodosa (Cebrian et al., 2000) and suggests that belowground detritus is more easily stored in the sediment than aboveground detritus. A mechanism supporting this hypothesis might be either (1) a higher belowground biomass and an associated higher supply of seagrass detritus or (2) higher recalcitrance of belowground detritus. Here, a higher supply is more likely because at our sites the belowground biomass is among the highest reported values for each species (Duarte and Chiscano, 1999), although the reported aboveground/belowground production ratio of $T$. hemprichii and E. acoroides varies among studies (Duarte et al., 1998; Duarte and Chiscano, 1999; Erftemeijer 
Table 3. Values of seagrass biomass organic carbon and sedimentary organic carbon mass in globally compiled data (Fourqurean et al., 2012) and this study (mean $\pm \mathrm{SD}, n$ ).

\begin{tabular}{|c|c|c|c|c|}
\hline & \multicolumn{2}{|c|}{ Vegetated } & \multicolumn{2}{|c|}{ No-vegetation } \\
\hline & $\begin{array}{r}\text { Seagrass biomass OC } \\
\left(\mathrm{gC} \mathrm{m}^{-2}\right) \\
\text { mean } \pm \mathrm{SD}(n)\end{array}$ & $\begin{array}{r}\text { Sedimentary OC } \\
\left(\mathrm{gC} \mathrm{L}^{-1}\right) \\
\text { mean } \pm \mathrm{SD}(n)\end{array}$ & $\begin{array}{r}\text { Seagrass biomass OC } \\
\left(\mathrm{gC} \mathrm{m}^{-2}\right) \\
\text { mean } \pm \mathrm{SD}(n)\end{array}$ & $\begin{array}{r}\text { Sedimentary OC } \\
\left(\mathrm{gCL}^{-1}\right) \\
\text { mean } \pm \mathrm{SD}(n)\end{array}$ \\
\hline Fourqurean et al. (2012) & $251.4 \pm 395.6(251)$ & $12.32 \pm 8.04(410)$ & - & $8.08 \pm 5.90(43)$ \\
\hline This study & $283.0 \pm 200.8(21)$ & $5.03 \pm 1.32(21)$ & - & $2.93 \pm 0.73(7)$ \\
\hline
\end{tabular}
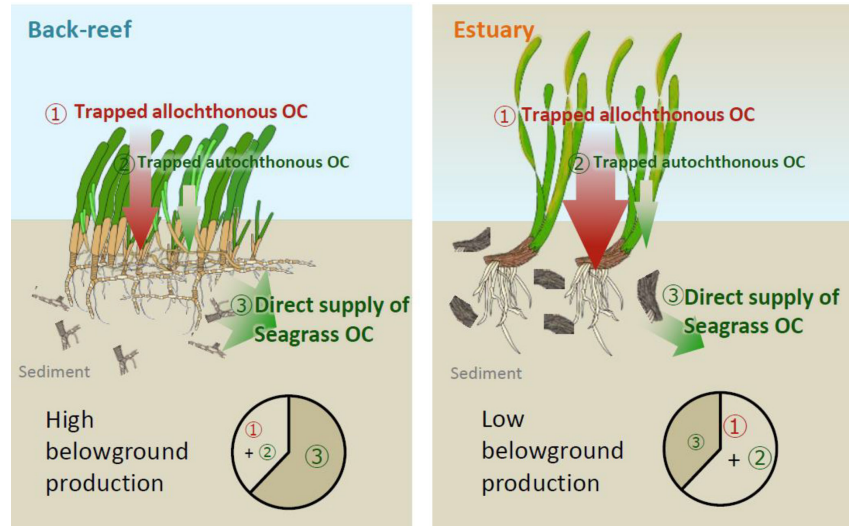

Figure 8. Proposed mechanisms of OC accumulation at our study sites. At the back-reef site dominated by Thalassia hemprichii, direct supply of recalcitrant belowground seagrass detritus is a major pathway of $\mathrm{OC}_{\text {sed }}$ accumulation. At the estuarine site dominated by Enhalus acoroides, trapping of suspended autochthonous and allochthonous OC is the major pathway of OC accumulation. A difference in the turnover rate of belowground biomass likely caused the major mechanism of $\mathrm{OC}$ accumulation to differ between the sites.

et al., 1993). Higher recalcitrance is also possible; Holmer and Olsen (2002) reported that during a 43-day decomposition experiment, E. acoroides rhizomes did not lose weight, whereas buried leaves lost $80.3 \pm 4.2 \%$ of their weight. Also, Fourqurean and Schrlau (2003) showed that only $5 \pm 2 \%$ of Thalassia testudinum leaves, but $49 \pm 6 \%$ of T. testudinum rhizomes, remained after 348 days of decomposition.

\subsection{Mechanism of the OC supply to sediment}

$\mathrm{OC}_{\text {sed }}$ was significantly and positively correlated with aboveground biomass at both sites (Fig. 7b) and with belowground biomass at the back-reef site (Fig. 7c). This result is contrary to the finding of most previous studies that there is no relationship between biomass and \%OC or OC mass (Kennedy et al., 2004, 2010; Howard et al., 2018; Rozaimi et al., 2017; but cf. Samper-Villarreal et al., 2016). This contrary result may be due to our data collection strategy of (1) sympatric sampling of all stock components (live and dead aboveground and belowground biomass and sediments) in intact cores, and (2) selection of sampling points aiming at controlling for variables other than seagrass biomass (i.e., mud content, wave height, and the amount of allochthonous OC inputs were relatively homogenous among points), although we could not exclude the possibility that our sites may have specific sedimentary OC storage characteristics different from those of other Indo-Pacific seagrass meadows. Several mechanisms can plausibly explain the positive relationship between seagrass biomass and $\mathrm{OC}_{\text {sed }}$, including (1) trapping of suspended OC (both allochthonous and autochthonous OC) by seagrass leaves, and (2) the direct supply of belowground seagrass-derived autochthonous OC. If it is assumed that the suspended OC settling on the sediment surface is spatially homogeneous in nature (quality) and that the contribution of trapped OC is larger than that of directly supplied OC, then $\delta^{13} \mathrm{C}_{\text {sed }}$ should be constant regardless of the aboveground biomass and its associated trapping capacity. However, $\mathrm{OC}_{\text {sed }}$ was significantly and positively correlated with $\delta^{13} \mathrm{C}_{\text {sed }}$ (Fig. 7e), and the average $\delta^{13} \mathrm{C}$ of $\mathrm{OC}_{\text {sed }}$ was significantly higher than $\delta^{13} \mathrm{C}$ values of allochthonous OC (algae and corals, suspended POM, and terrestrial POM) at the back-reef site (Fig. 6). Furthermore, $\mathrm{OC}_{\text {sed }}$ was positively correlated with $\mathrm{OC}_{\text {dead }}$ at both sites (Fig. 7d), and the main component of $\mathrm{OC}_{\text {dead }}$ was belowground detritus (Fig. 5d). Taken together, these results suggest that directly supplied seagrass-derived OC was mainly from the belowground detritus. The positive correlations between $\delta^{13} \mathrm{C}_{\text {sed }}$ and belowground biomass (Fig. 7f) and between $\delta^{13} \mathrm{C}_{\text {sed }}$ and $\mathrm{OC}_{\text {dead }}$ (Fig. 7g) at the back-reef site also support this mechanism. From these lines of evidence, we conclude that the direct supply of recalcitrant belowground seagrass detritus is a major mechanism of $\mathrm{OC}_{\text {sed }}$ accumulation at the back-reef site (Fig. 8). Although we inferred that a direct autochthonous OC supply from belowground biomass is the major mechanism of $\mathrm{OC}_{\text {sed }}$ accumulation, suspended allochthonous $\mathrm{OC}$ may also have been supplied from the water column at the back-reef site, as has been reported elsewhere (Kennedy et al., 2010), because the average $\delta^{13} \mathrm{C}_{\text {sed }}$ at the back-reef site was significantly lower than $\delta^{13} \mathrm{C}$ of seagrass (Fig. 6).

The seagrass-derived OC increase according to the development of the seagrass meadows at the back-reef site (Fig. 7a and e) suggests that seagrass meadows are autotrophic and the time since seagrass colonization is longer. This inference 
is consistent with a previous report that net primary production (NPP) at the back-reef site is higher where the seagrass cover is high (cover 91.7\%; NPP $68.14 \mathrm{mmol} \mathrm{C} \mathrm{m}^{-2} \mathrm{~d}^{-1}$ ) than where the seagrass cover is low (cover 55.1\%; NPP $34.20 \mathrm{mmol} \mathrm{C} \mathrm{m}^{-2} \mathrm{~d}^{-1}$ ) (Nakamura and Nakamori, 2009). It is also possible that seagrass mortality increases with time since colonization, leading to an increase in dead plant structures (Cebrian et al., 2000).

At the estuarine site, $\mathrm{OC}_{\text {sed }}$ increased with increasing aboveground seagrass biomass (Fig. 7b), but it did not increase with increasing belowground seagrass biomass (Fig. 7c), indicating that trapping of suspended OC by seagrass leaves surpassed the direct supply of belowground seagrass-derived OC (Fig. 8). However, $\mathrm{OC}_{\text {dead }}$ was significantly and positively correlated with $\mathrm{OC}_{\text {sed }}$ (Fig. 7d), indicating that direct supply also contributed to $\mathrm{OC}_{\text {sed }}$ accumulation at the site. A plausible mechanism explaining the hypothesized dominance of suspended OC trapping is a lower belowground turnover rate (i.e., the production / biomass ratio) at the estuarine site than at the back-reef site. Because $\mathrm{OC}_{\text {sed }}$ was not significantly different between the sites and directly supplied seagrass-derived OC was the major component of $\mathrm{OC}_{\text {sed }}$ at the back-reef site and only a minor component at the estuarine site, the capacity of the estuarine site to directly supply belowground seagrass-derived OC to the sediment was lower than that of the back-reef site (Fig. 8). Moreover, given that the directly supplied amount is determined by two factors, the belowground biomass and its turnover rate, and that the belowground biomass was not significantly different between the sites (Fig. 5a), we anticipate that a difference in the belowground turnover rate was responsible for the difference in the direct supply contribution between the sites. Another possible explanation for the inferred difference is that the absolute input of allochthonous OC was higher at the estuarine site than at the back-reef site. The slope of the regression between aboveground biomass and $\mathrm{OC}_{\text {sed }}$ was not significantly different between the sites (Fig. 7b), which suggests that the trapping ability for autochthonous and allochthonous OC was not different between the sites. However, the fact that $\mathrm{OC}_{\text {sed }}$ at vegetated points was not significantly different between the sites (Fig. 4b and d) together with the apparently minor direct belowground supply at the estuarine site implies that the contribution of OC from the water column to $\mathrm{OC}_{\text {sed }}$ was larger at the estuarine site. Moreover, the fact that average $\delta^{13} \mathrm{C}_{\text {sed }}$ was significantly lower at the estuarine site than at the back-reef site (Fig. 6) would support a major role of allochthonous OC from the water column in $\mathrm{OC}_{\text {sed }}$ accumulation. The effect of particle trapping by seagrasses is reported to be enhanced particularly in particle-poor waters (Duarte et al., 1999). Thus, trapping is likely to be an important mechanism especially at sites with particle-poor water such as coral reef sites.

\section{Conclusion}

Using our data collection strategy, namely, sympatric sampling in intact cores of live and dead seagrasses and sediments and analyses of the organic carbon mass and stable carbon isotope composition of all components of the cores, we successfully demonstrated the pathways of sedimentary $\mathrm{OC}$ accumulation in seagrass meadows and showed that the contributions of both a direct supply of seagrass-derived OC by belowground production and particle trapping are important, although the latter is generally assumed as the main mechanism of OC accumulation in seagrass meadows compared with the bare sediment sites. Our results indicate that it is critical to consider both belowground and aboveground biomass productivity in addition to the morphological complexity of seagrass meadows as factors controlling $\mathrm{OC}$, and that identifying the mechanism of accumulation is important for improving OC stock estimation and reducing the uncertainty in global blue carbon estimates.

Data availability. All raw data can be accessed at https://doi.org/10.5281/zenodo.1299640 (Tanaya, 2018).

Author contributions. TT, HK, and TK conceived the idea; TT, $\mathrm{KW}$, and TK designed the methodology; TT, KW, SY, and CH collected the samples and data; TT and KW performed sample analyses; TT and TK led the writing of the manuscript. All authors contributed critically to the drafts and gave final approval for publication.

Competing interests. The authors declare that they have no conflict of interest.

Acknowledgements. We thank Ryuji Tada for helpful comments; Atsushi Watanabe, Hiroyuki Takamiyagi, and Eizo Shimabukuro for the field sampling; Kiori Sakihara and Ayami Okuno for chemical analyses; Shigenori Ogihara, Takashi Muranaka, and Nobuhiro Koh for sample preparation; and Satoshi Kaku for developing the box corer. This study was partly supported by a Grant-in-Aid for Challenging Exploratory Research (no. 26630251) from the Japan Society for the Promotion of Science (JSPS), and by the Strategic R\&D Area Project (S-14) of the Environmental Research and Technology Development Fund of the Ministry of the Environment, Japan.

Edited by: Steven Bouillon

Reviewed by: two anonymous referees 


\section{References}

Agawin, N. S. and Duarte, C. M.: Evidence of direct particle trapping by a tropical seagrass meadow, Estuaries, 25, 1205-1209, https://doi.org/10.1007/BF02692217, 2002.

Barron, C., Marba, N., Terrados, J., Kennedy, H., and Duarte, C. M.: Community metabolism and carbon budget along a gradient of seagrass (Cymodocea nodosa) colonization, Limnol. Oceanogr., 49, 1642-1651, https://doi.org/10.4319/1o.2004.49.5.1642, 2004.

Borum, J., Sand-Jensen, K., Binzer, T., Pedersen, O., and Greve, T. M.: Oxygen movement in seagrasses, in: Seagrasses: biology, ecology and conservation, edited by: Larkum, A. W. D., Orth, R. J., and Duarte, C. M., Springer, Dordrecht, 255-270, 2006.

Cebrian, J., Pedersen, M. F., Kroeger, K. D., and Valiela, I.: Fate of production of the seagrass Cymodocea nodosa in different stages of meadow formation, Mar. Ecol.-Prog. Ser., 204, 119130, https://doi.org/10.3354/meps204119, 2000.

Dahl, M., Deyanova, D., Lyimo, L. D., Näslund, J., Samuelsson, G. S., Mtolera, M. S. P., Björk, M., and Gullström, M.: Effects of shading and simulated grazing on carbon sequestration in a tropical seagrass meadow, J. Ecol., 104, 654-664, https://doi.org/10.1111/1365-2745.12564, 2016.

Duarte, C. M. and Chiscano, C. L.: Seagrass biomass and production: a reassessment, Aquat. Bot., 65, 159-174, https://doi.org/10.1016/S0304-3770(99)00038-8, 1999.

Duarte, C. M., Merino, M., Agawin, N. S., Uri, J., Fortes, M. D., Gallegos, M. E., Marbà, N., and Hemminga, M. A.: Root production and belowground seagrass biomass, Mar. Ecol.-Prog. Ser., 171, 97-108, https://doi.org/10.3354/meps171097, 1998.

Duarte, C. M., Benavent, E., and del Carmen Sanchez, M.: The microcosm of particles within seagrass Posidonia oceanica canopies, Mar. Ecol.-Prog. Ser., 181, 289-295, https://doi.org/10.3354/meps181289, 1999.

Duarte, C. M., Marbà, N., Gacia, E., Fourqurean, J. W., Beggins, J., Barrón, C., and Apostolaki, E. T.: Seagrass community metabolism: Assessing the carbon sink capacity of seagrass meadows, Global Biogeochem. Cy., 24, GB4032, https://doi.org/10.1029/2010GB003793, 2010.

Duarte, C. M., Kennedy, H., Marba, N., and Hendriks, I.: Assessing the capacity of seagrass meadows for carbon burial: current limitations and future strategies, Ocean. Coast. Manage., 83, 32-38, https://doi.org/10.1016/j.ocecoaman.2011.09.001, 2013.

Erftemeijer, P. L., Osinga, R., and Mars, A. E.: Primary production of seagrass beds in South Sulawesi (Indonesia): a comparison of habitats, methods and species, Aquat. Bot., 46, 67-90, https://doi.org/10.1016/0304-3770(93)90065-5, 1993.

Fonseca, M. S. and Bell, S. S.: Influence of physical setting on seagrass landscapes near Beaufort, North Carolina, USA, Mar. Ecol.-Prog. Ser., 171, 109-121, https://doi.org/10.3354/meps171109, 1998

Fourqurean, J. W. and Schrlau, J. E.: Changes in nutrient content and stable ratios of $\mathrm{C}$ and $\mathrm{N}$ during decomposition of seagrasses and mangrove leaves along a nutrient availability gradient in Florida bay, USA, Chem. Ecol., 19, 373-390, https://doi.org/10.1080/02757540310001609370, 2003.

Fourqurean, J. W., Duarte, C. M., Kennedy, H., Marbà, N., Holmer, M., Mateo, M. A., Apostolaki, E. T., Kendrick, G. A., KrauseJensen, D., McGlathery, K. J., and Serrano, O.: Seagrass ecosys- tems as a globally significant carbon stock, Nat. Geosci., 5, 505509, https://doi.org/10.1038/ngeo1477, 2012.

Gacia, E. and Duarte, C. M.: Sediment retention by a Mediterranean Posidonia oceanica meadow: the balance between deposition and resuspension, Estuar. Coast. Shelf S., 52, 505-514, https://doi.org/10.1006/ecss.2000.0753, 2001.

Gacia, E., Granata T. C., and Duarte, C. M.: An approach to measurement of particle flux and sediment retention within seagrass (Posidonia oceanica) meadows, Aquat. Bot., 65, 255-268, https://doi.org/10.1016/S0304-3770(99)00044-3, 1999.

Gacia, E., Duarte, C. M., Marba, N., Terrados, J., Kennedy, H., Fortes, M. D., and Tri, N. H.: Sediment deposition and production in SE-Asia seagrass meadows, Estuar. Coast. Shelf S., 56, 909-919, https://doi.org/10.1016/S0272-7714(02)00286$\mathrm{X}, 2003$.

Green, E. P. and Short, F. T. (Eds.): World atlas of seagrasses, University of California Press, Berkeley, 2003.

Hemminga, M. A., Slim, F. J., Kazungu, J., Ganssen, G. M., Nieuwenhuize, J., and Kruyt, N. M.: Carbon outwelling from a mangrove forest with adjacent seagrass beds and coral reefs (Gazi Bay, Kenya), Mar. Ecol.-Prog. Ser., 106, 291-301, https://doi.org/10.3354/meps 106291, 1994.

Hendriks, I. E., Sintes, T., Bouma, T. J., and Duarte, C. M.: Experimental assessment and modeling evaluation of the effects of the seagrass Posidonia oceanica on flow and particle trapping, Mar. Ecol.-Prog. Ser., 356, 163-173, https://doi.org/10.3354/meps07316, 2008.

Holmer, M. and Olsen, A. B.: Role of decomposition of mangrove and seagrass detritus in sediment carbon and nitrogen cycling in a tropical mangrove forest, Mar. Ecol.-Prog. Ser., 230, 87-101, https://doi.org/10.3354/meps230087, 2002.

Howard, J. L., Creed, J. C., Aguiar, M. V. P., and Fouqurean, J. W.: $\mathrm{CO}_{2}$ released by carbonate sediment production in some coastal areas may offset the benefits of seagrass "Blue Carbon" storage, Limnol. Oceanogr., 63, 160-172, https://doi.org/10.1002/lno.10621, 2018.

Ingalls, A. E., Lee, C., and Druffel, E. R.: Preservation of organic matter in mound-forming coral skeletons, Geochim. Cosmochim. Ac., 67, 2827-2841, https://doi.org/10.1016/S00167037(03)00079-6, 2003.

Kennedy, H., Gacia, E., Kennedy, D. P., Papadimitriou, S., and Duarte, C. M.: Organic carbon sources to SE Asian coastal sediments, Estuar. Coast. Shelf S., 60, 59-68, https://doi.org/10.1016/j.ecss.2003.11.019, 2004.

Kennedy, H., Beggins, J., Duarte, C. M., Fourqurean, J. W., Holmer, M., Marbà, N., and Middelburg, J. J.: Seagrass sediments as a global carbon sink: isotopic constraints, Global Biogeochem. Cy., 24, GB4026, https://doi.org/10.1029/2010GB003848, 2010.

Kirkman, H.: Seagrasses of Australia. State of the Environment Technical Paper Series (Estuaries and the Sea), Department of the Environment, Canberra, 1997.

Koch, E. W.: Beyond light: physical, geological, and geochemical parameters as possible submersed aquatic vegetation habitat requirements, Estuaries, 24, 1-17, https://doi.org/10.2307/1352808, 2001.

Kuwae, T., Beninger, P. G., Decottignies, P., Mathot, K. J., Lund, D. R., and Elner, R. W.: Biofilm grazing in a higher vertebrate: the western sandpiper, Calidris mauri, Ecology, 89, 599-606, https://doi.org/10.1890/07-1442.1, 2008. 
Lavery, P. S., Mateo, M.-A., Serrano, O., and Rozaimi, M.: Variability in the Carbon Storage of Seagrass Habitats and Its Implications for Global Estimates of Blue Carbon Ecosystem Service, PLOS ONE, 8, e73748, https://doi.org/10.1371/journal.pone.0073748, 2013.

Lee, K. S., Park, S. R., and Kim, Y. K.: Effects of irradiance, temperature, and nutrients on growth dynamics of seagrasses: a review, J. Exp. Mar. Biol. Ecol., 350, 144-175, https://doi.org/10.1016/j.jembe.2007.06.016, 2007.

Mcleod, E., Chmura, G. L., Bouillon, S., Salm, R., Björk, M., Duarte, C. M., Lovelock, C. E., Schlesinger, W. H., and Silliman, B. R.: A blueprint for blue carbon: toward an improved understanding of the role of vegetated coastal habitats in sequestering $\mathrm{CO}_{2}$, Front. Ecol. Environ., 9, 552-560, https://doi.org/10.1890/110004, 2011.

Mitsumoto, H., Omija, T., and Kobayashi, R.: Water pollution caused by soil run-off and the coral reef situation in Shiraho, Ishigaki Island 2, Annual Report of Okinawa Prefectural Institute of Health and Environment, 34, 121-124, 2000 (in Japanese).

Miyajima, T., Koike, I., Yamano, H., and Iizumi, H.: Accumulation and transport of seagrass-derived organic matter in reef flat sediment of Green Island, Great Barrier Reef, Mar. Ecol.-Prog. Ser., 175, 251-259, https://doi.org/10.3354/meps175251, 1998.

Miyajima, T., Hori, M., Hamaguchi, M., Shimabukuro, H., Adachi, H., Yamano, H., and Nakaoka, M.: Geographic variability in organic carbon stock and accumulation rate in sediments of East and Southeast Asian seagrass meadows, Global Biogeochem. Cy., 29, 397-415, https://doi.org/10.1002/2014GB004979, 2015.

Miyajima, T., Hori, M., Hamaguchi, M., Shimabukuro, H., and Yoshida, G.: Geophysical constraints for organic carbon sequestration capacity of Zostera marina seagrass meadows and surrounding habitats, Limnol. Oceanogr., 62, 954-972, https://doi.org/10.1002/lno.10478, 2017.

Nakamura, T. and Nakamori, T.: Estimation of photosynthesis and calcification rates at a fringing reef by accounting for diurnal variations and the zonation of coral reef communities on reef flat and slope: a case study for the back reef site, Ishigaki Island, southwest Japan, Coral Reefs, 28, 229-250, https://doi.org/10.1007/s00338-008-0454-8, 2009.

Nellemann, C., Corcoran, E., Duarte, C. M., Valdés, L., De Young, C., Fonseca, L., and Grimsditch, G.: Blue Carbon. The Role of Healthy Oceans in Binding Carbon. A Rapid Response Assessment 78, United Nations Environment Programme, GRIDArenal, 2009.

Pendleton, L., Donato, D. C., Murray, B. C., Crooks, S., Jenkins, W. A., Sifleet, S., Craft, C., Fourqurean, J. W., Kauffman, J. B., Marbà, N., Megonigal, P., Pidgeon, E., Herr, D., Gordon, D., and Baldera, A.: Estimating global "blue carbon" emissions from conversion and degradation of vegetated coastal ecosystems, PLOS ONE, 7, e43542, https://doi.org/10.1371/journal.pone.0043542, 2012.

Ricart, A. M., York, P. H., Rasheed, M. A., Pérez, M., Romero, J., Bryant, C. V., and Macreadie, P. I.: Variability of sedimentary organic carbon in patchy seagrass landscapes, Mar. Pollut. Bull., 100, 476-482, https://doi.org/10.1016/j.marpolbul.2015.09.032, 2015.

Rozaimi, M., Fairoz, M., Hakimi, T. M., Hamdan, N. H., Omar, R., Ali, M. M., and Tahirin, S. A.: Carbon stores from a tropical seagrass meadow in the midst of an- thropogenic disturbance, Mar. Pollut. Bull., 119, 253-260, https://doi.org/10.1016/j.marpolbul.2017.03.073, 2017.

Samper-Villarreal, J., Lovelock, C. E., Saunders, M. I., Roelfsema, C., and Mumby, P. J.: Organic carbon in seagrass sediments is influenced by seagrass canopy complexity, turbidity, wave height, and water depth, Limnol. Oceanogr., 61, 938-952, https://doi.org/10.1002/lno.10262, 2016.

Serrano, O., Lavery, P. S., Rozaimi, M., and Mateo, M. Á.: Influence of water depth on the carbon sequestration capacity of seagrasses, Global Biogeochem. Cy., 28, 950-961, https://doi.org/10.1002/2014GB004872, 2014.

Serrano, O., Lavery, P. S., Duarte, C. M., Kendrick, G. A., York, P. H., and Macreadie, P. I.: Can mud (silt and clay) concentration be used to predict soil organic carbon content within seagrass ecosystems?, Biogeosciences, 13, 4915-4926, https://doi.org/10.5194/bg-13-4915-2016, 2016a.

Serrano, O., Ricart, A. M., Lavery, P. S., Mateo, M. A., AriasOrtiz, A., Masque, P., Rozaimi, M., Steven, A., and Duarte, C. M.: Key biogeochemical factors affecting soil carbon storage in Posidonia meadows, Biogeosciences, 13, 4581-4594, https://doi.org/10.5194/bg-13-4581-2016, 2016b.

Short, F., Carruthers, T., Dennison, W., and Waycott, M.: Global seagrass distribution and diversity: a bioregional model, J. Exp. Mar. Biol. Ecol., 350, 3-20, https://doi.org/10.1016/j.jembe.2007.06.012, 2007.

Suzuki, R.: Sediment production by Echinometra mathaei in the shallow littoral zone of coral reefs, the Ishigaki island, Ryukyus, Japan, J. Geogr., 114, 41-57, https://doi.org/10.5026/jgeography.114.41, 2005.

Tamura, H., Nadaoka, K., and Paringit, E. C.: Hydrodynamic characteristics of a fringing coral reef on the east coast of Ishigaki Island, southwest Japan, Coral Reefs, 26, 17-34, https://doi.org/10.1007/s00338-006-0164-z, 2007.

Tanaka, Y. and Kayanne, H.: Relationship of species composition of tropical seagrass meadows to multiple physical environmental factors, Ecol. Res., 22, 87-96, https://doi.org/10.1007/s11284006-0189-3, 2007.

Tanaya, T.: Contributions of the direct supply of belowground seagrass detritus and trapping of suspended organic matter to the sedimentary organic carbon stock in seagrass meadows, https://doi.org/10.5281/zenodo.1299640, 2018.

Terada, K., Koibuchi, Y., and Isobe, M.: Material flux in mangrove forest based on the field observation, Proceedings of Coastal Engineering, Japan Society of Civil Engineers, 54, 1056-1060, https://doi.org/10.2208/proce1989.54.1056, 2007 (in Japanese).

Trevathan-Tackett, S. M., Macreadie, P. I., Sanderman, J., Baldock, J., Howes, J. M., and Ralph, P. J.: A global assessment of the chemical recalcitrance of seagrass tissues: implications for long-term carbon sequestration, Front. Planet. Sci., 8, 925, https://doi.org/10.3389/fpls.2017.00925, 2017.

Versteegh, E. A. A., Gillikin, D. P., and Dehairs, F.: Analysis of $\delta^{15} \mathrm{~N}$ values in mollusk shell organic matrix by elemental analysis/isotope ratio mass spectrometry without acidification: an evaluation and effects of long-term preservation, Rapid Commun. Mass Sp., 25, 675-680, https://doi.org/10.1002/rcm.4905, 2011.

Watanabe, K. and Kuwae, T.: How organic carbon derived from multiple sources contributes to carbon sequestration processes in 
a shallow coastal system?, Glob. Change Biol., 21, 2612-2623, https://doi.org/10.1111/gcb.12924, 2015.
Yamamuro, M. and Kayanne, H.: Rapid direct determination of organic carbon and nitrogen in carbonate-bearing sediments with a Yanaco MT-5 CHN analyzer, Limnol. Oceanogr., 40, 1001-1005, https://doi.org/10.4319/lo.1995.40.5.1001, 1995. 